\title{
Sex Slavery in India: Unpacking the Stories of Trafficking Victims*
}

\author{
Madhumita Pandeya
}

\begin{abstract}
While there is no consensus on the number of domestic sex trafficking victims in India, the phenomenon is estimated to be widespread and the evidence of its impact on victims is devastating. This paper explored the narratives of 10 sex trafficked women from a major non-government organization in New Delhi. Qualitative methodology was adopted and data were collected through open-ended unstructured interviews. The victimological paradigm including the Lifestyle Risk Model (LRM) by Van der Hoven and Maree provided the framework to discuss the key issues related to sex trafficking. Psychological experiences such as being abused by husbands, and in some cases, victims' own families; social conditions such as poverty and education; cultural practices such as vulnerability of women and marginalization; and lifestyle risk factors were observed throughout the stories of the victims. Furthermore, shame was found to be the core emotion in the stigmatization process. Limitations and future directions are also discussed.
\end{abstract}

\section{Keywords}

Sex trafficking, prostitution, India, women, sexual abuse, shame

Every year, a large number of persons are trafficked all around the world where they find themselves in an exploitative situation for economic gain. This global epidemic comes at an innumerable human cost and highlights the most disgraceful aspects of the world-modern slavery. According to the UN Palermo Protocol Article 3 (United Nations Office on Drugs and Crime 2000), trafficking is defined as:

The recruitment, transportation, transfer, harbouring or receipt of persons, by means of the threat or use of force or other forms of coercion, of abduction, of fraud, of deception, of the abuse of power or of a position of vulnerability or of the giving or receiving of payments or benefits to achieve the consent of a person having control over another person, for the purpose of exploitation. Exploitation shall include, at a minimum, the exploitation of the prostitution of others or other forms of sexual exploitation, forced labour or services, slavery or practices similar to slavery, servitude or the removal of organs.
Almost a nine billion US dollar industry, trafficking is assessed to be the fasted developing venture of the twenty-first century (United Nations Office on Drugs and Crime 2012). Recent instances of violence against women worldwide and particularly in India have renewed research interest in the trafficking of women and young girls due to its close connection to the exploitative sex industry.

According to Huda (2006), Asia has been highlighted as one of the most vulnerable regions for trafficking due to growing urbanization, population, and ever-existing poverty. The special report on

aAnglia Ruskin University, Cambridge, United Kingdom

\section{Correspondent Author:}

Madhumita Pandey, Department of Criminology, Anglia Ruskin University, Helmore Building, East Road, Cambridge CB1 1PT, United Kingdom 
trafficking in persons by the United Nations Office of the High Commissioner for Human Rights (2015) estimated that some 30 million Asian women and young girls have been victims of sexual exploitation over the last three decades alone. Furthermore, the largest number of victims of sex trafficking emerged from South Asia, an estimate of 150,000 annually.

Trafficking of women and young girls is a serious and widespread problem in India (Hameed et al. 2010). The U.S. State Department (2009) recognized India as both a transit and source country for trafficking along with also being a popular destination in South Asia. Trafficking patterns in India indicate that about 90\% of the trafficking is domestic (intra-state and inter-state) with only $10 \%$ taking place across international borders (Nair and Sen 2004). India maintains close border proximity with its immediate neighbours and out of the girls trafficked into India, most come from Pakistan, Bangladesh, Nepal, Myanmar, and Cambodia (Silverman et al. 2007). Given India's size and diversity, trafficking trends differ across all 29 states (United Nations Office on Drugs and Crime 2009). Trafficked victims are exploited in various ways, which include begging, domestic work, forced prostitution, bonded or agricultural labour, entertainment sector, and organ donation (Khan N.d.). However, this paper is going to focus on sex trafficking in India.

India's sex industry includes some two million sex-workers, out of which, $20 \%$ are under the age of 16 (Nair and Sen 2004). In a study conducted by Silverman et al. (2007) with victims of sex trafficking, it was found that one in six girls were under the age of $16,51.9 \%$ were trafficked as a minor, $59.7 \%$ reported that their trafficker were known to them, of promises made, economic opportunity was the primary attraction in more than half of the sample (55\%) and lastly, $49.4 \%$ reported some sort of family disruption (violence involving the spouse or other family members) as a direct cause of them being trafficked. It was concluded that the interaction of poverty, lack of education, gender-based discrimination, and ill treatment of women in India heightens the risk of sex trafficking.

\section{THEORETICAL BACKGROUND}

Various theories provide an integrated framework to understand and explain the occurrence of sex trafficking. Lanier and Henry (2004) believed that when there are several triggers or causes for a crime, a conceptual synthesis is essential to analyze the sequential chain of events. The victimological paradigm contains several concepts that explain why certain women might be at a greater risk of being victimized than others and serves a great purpose in understanding the risk factors associated with sex trafficking. According to Lutya and Lanier (2012), relationships and interactions with trafficker, repeat victimization and lifestyle as a factor are key for describing the nature of victimization of human trafficking for involuntary prostitution. For the purpose of this research, our focus will be on the lifestyle risk model of victimization.

\section{Lifestyle Risk Model}

Van der Hoven and Maree (2005) described the risk of victimization to be related to personality and routines of potential victims, absence of capable guardians, and environmental factors. They discussed how someone's daily interactions and activities could determine the type of victimization one could experience. For example, substance abuse by a family member may lead to interpersonal violence, or negligence whereas the use of the Internet may expose someone to inappropriate deviant online social groups. Lifestyle activities involving victims from India mostly consist of a demographic characteristic which is poor and uneducated (Silverman et al. 2007), as well as of women who are already victims of abandonment, marginalization, and abuse which highlights the role of these factors in explaining human trafficking of 
young women and girls for involuntary prostitution. Van der Hoven and Maree (2005) also argued that it is most likely that the traffickers pick victims from familiar places after observing their lifestyle, understanding how gullible and prone they are, which also ensures a low possibility of the victims reporting the traffickers to the authorities.

In summary, victim's vulnerability is the main variable selected to explain human trafficking of women and girls for involuntary prostitution in this research.

\section{Sexual Abuse and Shame}

It is not uncommon for sex trafficked women and young girls to be subjected to sexual abuse by their trafficker or clients (Brown 2000; Kara 2009). Finkelhor and Browne (1986) stressed on the relationship between sexual abuse and stigmatization. According to Feiring, Taska, and Lewis (1996), sexual abuse is most likely to result in negative self-evaluation: emotion of shame. They believed that it is not guilt but shame that is the core emotion of stigmatization process. Furthermore, research has also shown that victims prone to shame are more likely to evidence depression, poor self-esteem, and dissociation (Ross 1989; Tangney et al. 1992; Lewis 1992).

Current study employed a sample of women and young girls from New Delhi, India who were rescued by a major non-government organization (NGO) and were residing in their shelter home. The narratives collected from this sample were explored to understand the various risk factors associated with sex trafficking in India and also looked at stigmatization and its role in the rehabilitation of the victims.

\section{METHODS}

\section{Participants}

The sample included 10 women from a major NGO shelter home in New Delhi who were victims of sex trafficking. Some of them were rescued during brothel raids and others had run away from the red light districts and sought help at the shelter home. They were staying for a temporary period to get health care, legal assistance, mental health counselling, career guidance, and protection.

\section{Measures}

The study used two measures for collecting data from the sample:

(1) Demographics questionnaire. A demographics questionnaire was developed to get the basic personal information from the participants. The questionnaire comprised of five main questions related to age, education, religion, marital status, and place of trafficking.

(2) Interview sheet. Oral narratives were collected from the participants with the help of an open-ended semi-structured interview sheet. This sheet comprised of questions related to the victim's upbringing, their lifestyle, their relationships, and other related experiences before and after being trafficked. The interview sheet was used as a prompt during the data collection to help steer the conversation towards the research questions as well as to keep a track of the information needed for the study.

\section{Ethical Considerations}

Due to the sensitive nature of the study and the participants involved, a number of ethical considerations were undertaken. Before the commencement of the research study, permission was obtained from the director of the NGO. A risk assessment was also conducted and approved by the NGO psychologist. After the permissions were granted, participants were provided with an information sheet describing fully the purpose of the research, the risks and benefits involved, and explaining their right to the confidentiality of data. Informed written consent was obtained and each participant was given a participant ID to ensure anonymity. 
The research adhered to all the British Psychological Society (BPS) (2010) guidelines "Code of Ethics and Conduct", and did not involve the breaching of ethical standards in any way. Should the participants become distressed at any point in time during the course of the study, they had immediate access to the NGO psychologist and counsellor.

\section{RESULTS}

\section{Sample Demographics}

Seventy percent of the victims $(n=7)$ were trafficked within India, with Bangladesh being the second place of origin $(n=2)$ and Nepal third $(n=1)$. Most of the trafficked victims $(80 \%)$ were minors except for two who were trafficked at the age of 20 . The victims had worked in brothels in different parts of the country, however, were rescued from Delhi or subsequently had managed to escape to Delhi. Almost all of them (90\%) had no formal education, except one who had attended primary school but due to the rural location of the village, the school facilities were very basic. Three were married, one was separated from her husband, and the rest $(60 \%)$ were never married before. Table 1 shows the demographic characteristics of the participants.

\section{Recruitment Tactics and Relationship to Trafficker}

The majority of the victims $(80 \%)$ reported that the trafficker on promises of economic opportunities lured them. The remaining women $(20 \%)$ were victims of false marital/love promises. Except for two women who were lured by false marital/love promises, victims recalled no previous relationship with the trafficker.

\section{Transportation Modes}

All the victims reported to be trafficked from public areas in major cities. The most common places reported by victims were public bus or train transit stations. Victims who were trafficked from across the international borders $(n=3)$ reported being driven in a private vehicle for some duration of the commute.

\section{Predisposing Family Factors}

Although all women and girls described poverty as a predisposing factor contributing to their vulnerability to being trafficked, more than half of them $(60 \%)$ also reported familial disruption as a major factor. The most common form of family disruption was physical/sexual abuse, $40 \%$ reported abuse by spouse or in-laws, which further led to distress because of marital separation. Younger victims (30\%) reported violence from non-spousal family members along with alcoholism, abandonment, and debt issues as factors responsible for disruptions.

\section{DISCUSSIONS}

The present research provided narratives that highlighted various contexts for vulnerability for sex trafficking in India. These narratives were organized using Nvivo software but were largely analysed manually. Findings showed that $80 \%$ of the sample (n $=8$ ) was trafficked for prostitution as minors (under the age of 18 years). This highlights the existing concern for sex trafficking of minor girls in South Asia (Nair 2004; Hennink and Simkhada 2004). Furthermore, it raises concerns with regard to the rights of children in India (Indian Penal Code-Immoral Trafficking Prevention Act 1956, which was amended in 1986) as well as of the international world (United Nations Conventions on Child Rights, Article 34 1989).

Various researchers who support the victim's vulnerability model have studied lifestyle factors. Van der Hoven and Maree (2005) discussed in their lifestyle risk model how a trafficker might seldom pick a victim from strange surroundings. They often keep a track of the several factors which are key in 
Table 1. Demographic Characteristics of Sex Trafficking Victims $(n=10)$

\begin{tabular}{|c|c|c|}
\hline$\overline{\text { Characteristics }}$ & $\overline{\mathrm{N}}$ & Percent (\%) \\
\hline \multicolumn{3}{|l|}{ Nation of origin } \\
\hline India & 7 & 70 \\
\hline Nepal & 1 & 10 \\
\hline Bangladesh & 2 & 20 \\
\hline \multicolumn{3}{|l|}{ City of trafficking } \\
\hline New Delhi & 5 & 50 \\
\hline Mumbai & 1 & 10 \\
\hline Kolkata & 3 & 30 \\
\hline Hyderabad & 1 & 10 \\
\hline \multicolumn{3}{|l|}{ Religion } \\
\hline Hindu & 5 & 50 \\
\hline Muslim & 3 & 30 \\
\hline Christian & 2 & 20 \\
\hline \multicolumn{3}{|l|}{ Marital status } \\
\hline Never married & 6 & 60 \\
\hline Married & 3 & 30 \\
\hline Separated & 1 & 10 \\
\hline \multicolumn{3}{|l|}{ Education } \\
\hline Primary & 1 & 10 \\
\hline Illiterate/uneducated & 9 & 90 \\
\hline \multicolumn{3}{|l|}{ Age at trafficking } \\
\hline 14 and under & 3 & 30 \\
\hline 15 to 17 years & 5 & 50 \\
\hline 18 to 20 years & 2 & 20 \\
\hline
\end{tabular}

making their target more prone and vulnerable to being trafficked. Several such factors were observed throughout the narratives of the participants.

\section{Poverty}

According to United Nation's Millennium Development Goal (MDG) programme, during 2011-2012, 270 million people out of 1.2 billion population of India lived below the poverty line (with an income of $\$ 1.25 /$ day).

One of the participants said in her interview, "Having no money made things worse. All we could manage to eat was wild roots and to even have one proper meal seemed impossible". She further added, "Since my father was a drunk, mother had to work as a maid as well as in the fields to make some money". Another participant recalled, "My father just a local farmer in the village. We were poor and had a simple life. There were eight brothers and sisters in total. With a family that large, not everyone's needs were met easily. Some days were very unpleasant".

Current findings highlighted the compelling nature of poverty as a factor in sex trafficking, as $80 \%$ of the women were lured on the basis of economic promises. Researchers (Huda 2006; Okonofua et al. 2004; Skeldon 2000) have previously discussed the role of poverty as a predisposing factor to sex trafficking in South Asia as well as other parts of the world.

\section{Education}

Education is another vital factor that plays a role in sex trafficking. According to United Nations Development Report (UNDP 2007), India has the 
largest number of illiterates in the world (53.2\%). In our sample, $90 \%$ of the victims reported having no formal education, with only one attending primary school in her local village in Bangladesh.

One of the participants said in her interview, "No, I never went to school. I learned all the household chores to assist my mother. Since my father was a drunk, she had to work as a maid as well as in the fields to make some money. I never had the time".

Another one added,

School was free; it wasn't so much about the paying for education as opposed to the use of it. My father would say why do you need to study, your mother survived just all right and she never went to school. He also felt that it took time away from the day, which could be utilized in helping around the house.

In a study conducted by Silverman et al. (2007) with sex trafficking victims in Mumbai, India, it was also found that more than half of their sample had no formal education. Education also plays a key role in the formation of attitudes towards women, particularly with how women recognize their own victimization and society's responses towards violence agaisnt women (Flood and Pease 2009).

\section{Cultural Factors}

India is known to be a predominantly patriarchal society. Women are subjected to violence and abuse, stigmatization, and marginalization due to several traditional gender norms. These cultural factors play a significant role in making women vulnerable to sex trafficking. Current findings found that about $40 \%$ of the sample had been subjected to physical or sexual violence, particularly from the spouse or the in-laws. One of the participants recalls,

The reason why I left my village was dowry harassment. My parents were unable to pay my bridal price (dowry) because of which my husband and his family made my life a torment. After five years of torture and mistreatment, I sold off the two things of value I had been given by my mother-a necklace and two bangles for some money to travel to Hyderabad in search of work.

Women and Child Development Ministry of India reported that $8,233,8,083$, and 8,455 cases were registered under section 304B of the Indian Penal Code (Dowry Death) in the country in 2012, 2013, and 2014 respectively.

Similarly, another participant said in their interview,

It was very soon after my menstruation that my mother arranged my marriage with a man who was almost my father's age. I felt like I was burden on my family. I didn't want to get married but I couldn't do anything about it. I was a little bit relieved knowing I'll leave my house and my husband will treat me well but my fate was cursed. The man I married was worse anything I had imagined. He raped and abused me all night. I remember crying out and shouting with pain but he said, "This is the main reason for which I married you and as a wife you are deserved for this". He tried stuffing little stones and other objects in my vagina. He was psycho. I was so young and didn't even know what to do with my life. Everything seemed doomed. One day after he almost slammed open my head when I refused to have sex with him, I thought this was it.

Even though child marriage is illegal in India, the country has the highest number of child brides in the world. According to the Prohibition of Child Marriages Act (2006), girls cannot marry below the age of 18 and boys below the age of 21 years. However, it is estimated that $47 \%$ of girls in India are married before the legal age (UNICEF 2015). A National Action Plan to prevent child marriages was drafted by the Ministry of Women and Child Development in 2013, however, it has not yet been finalized (HAQ: Centre for Child Rights 2010).

Similarly, Indian criminal justice system does not consider martial rape as an offence. It was found that $65 \%$ of Indian men believed that women should tolerate violence in order to keep the family together, and women sometimes deserve to be beaten (International Center for Research on Women 2011). 
Furthermore, the International Men and Gender Equality Survey (IMAGES 2011) Questionnaire reported that $24 \%$ of Indian men had committed sexual violence at some point during their lives.

Women also find it hard to be accepted back into their families after they are abandoned by the husbands or have willingly left their husband's homes. One of the participants said,

I had had enough abuse and left my husband's house to go and live with my mother. She obviously wasn't too pleased that I had returned and told me that it was my duty to please my husband. I left like I was a burden on them and they feared getting a bad name in the village.

Further, the stigmatization of families of such victims related to status in the community leads to a reluctance to offer support or shelter to the women (Goel 2005). According to Fikree and Pasha (2004), traditional cultural norms continue to dominate most of the rural Indian society wherein the sons are considered favourable as they are associated with economic advantage and girls are considered as social burden, and most of the time, the family is unable or unwilling to support unmarried, divorced, or widowed females (Silverman et al. 2007). By extension, limited economic opportunities for women experiencing gender-based violence and abdandonment have been found to contribute to the increased likelihood of victimization which may lead them to undertake risky employment options (Go et al. 2003; Krishnan 2005).

\section{Shame and Abuse}

Many researches have found that it is quite common for sex trafficked women and young girls to be subjected to sexual abuse by their trafficker or clients (Brown 2000; Kara 2009). Finkelhor and Browne (1986) stressed on the relationship between sexual abuse and stigmatization. According to Feiring et al. (1996), sexual abuse most likely leads to negative self-evaluation and development of shame as a strong core emotion. These negative feelings were observed throughout the narratives of our sample. Women felt that they were carrying the shame from their old life and even though they were getting psychological assistance, they thought it would be very difficult to overcome this feeling. One of the participants said,

On no, I can never be the girl that I was when I first got married. The world still sees me as a prostitute. I am worried that someone might recognize me, that I might cross paths with my pimp again. I am terrified of it. My family didn't understand what I went through and were ashamed of me. I am shamed of me.

Another woman had been diagnosed with HIV after being rescued. She said,

No, I wouldn't even dream of returning home. I'd rather have my mother think that I am dead than to tell her what happened to me. I blame myself for trusting those men and also for not trying to make things work with my husband. I know if I returned the whole village will think I am a bad influence and that I am bringing shame to everyone. No one will understand that's why I don't even want to try. I feel sick most of the time and I am just glad that if I die, it won't be in that hell-hole.

Some of them also stressed on how it was shame and not guilt that they were carrying, since most of them were trafficked due to their unfortunate circumstances, they did not think it was their fault.

Will I go back you ask? All this time I wanted to but now when I look at my life in retrospect I think I don't have the courage to go back even when it was my family who made me walk down this path. I am not their little girl anymore. I don't have any guilt but I resent myself sometimes. I am always thinking about how others look at me and I feel ashamed.

Based on the themes that emerged from the narratives, a word cloud was also generated in Nvivo. Figure 1 shows the word frequency cloud.

In summary, lifestyle risk factors play an important role in victimization and the findings regarding the nature of risk factors for trafficking are consistent with 


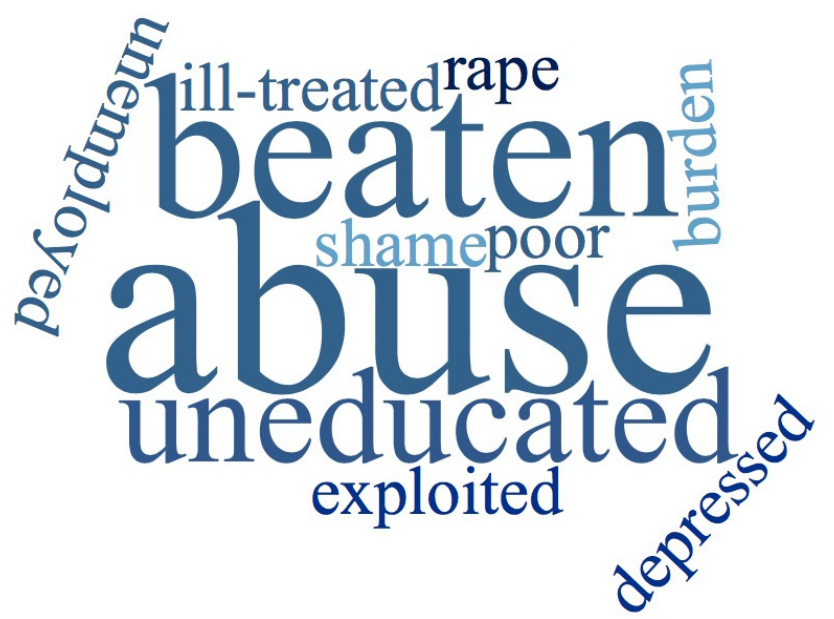

Figure 1. Word Frequency Cloud Generated for the Major Themes.

reports from both the UN Special Rapporteur on Trafficking in Persons and other major South Asian NGOs.

\section{LIMITATIONS AND FUTURE SUGGESTIONS}

As with all qualitative research, there are some general limitations such as sample size and generalizability of the main findings. This research was based on a small sample collected from a single organization from a single major city in India. Given the vast size of India, trafficking patterns vary regionally, thus data should be collected from multiple cities with bigger sample sizes in order to represent a broader range of demographics and experiences. This is likely to improve the generalization of results for the victims of sex trafficking in India.

Having said that, qualitative research also has its advantages when employed even with a small sample size. The richness of individual in-depth narratives can shed light on the subjective lived experiences of the victims. Such type of data is also useful with regard to policy reforms.

Sex trafficking was traditionally studied from the lens of reproductive and sexual health with special emphasis on the spread of HIV and AIDS. However, research now includes metal health as well as social perspectives when addressing this issue. Medical practitioners, social workers, and policy makers should work together in order to develop an integrated and comprehensive framework, which can practically aim at reducing the problem of sex trafficking.

The signing of the Convention on Preventing and Combating the Trafficking in Women and Children for Prostitution in the 2002 South Asian Association for Regional Cooperation (SAARC) summit points towards a joint international political commitment to address this issue. A focus on prevention and rehabilitation by understanding victimology behind sex trafficking must be included in the mainstream research discourse and policy considerations.

\section{CONCLUSIONS}

This research explored the narratives of 10 sex trafficked women from a major NGO in New Delhi. Qualitative methodology was adopted for this study. Psychological experiences such as being abused by husbands, and in some cases, victims' own families; social conditions such as poverty and illiteracy; 
cultural practices such as vulnerability of women and marginalization; and lifestyle risk factors were observed throughout the stories of the victims. Furthermore, shame was found to be the core emotion in the stigmatization process and a possible hurdle in the successful psychological rehabilitation of the victims.

\section{Note}

* This research was also featured in Asia Times. Retrieved (http://www.atimes.com/article/human-trafficking-india-an usha/).

\section{References}

Brown, T. L. 2000. Sex Slaves: The Trafficking of Women in Asia. United Kingdom: Virago Press.

Browne, A. and D. Finkelhor. 1986. "Impact of Child Sexual Abuse: A Review of the Research." Psychological Bulletin 99(1):66-77.

Feiring, C., L. Taska, and M. Lewis. 1996. "A Process Model for Understanding Adaptation to Sexual Abuse: The Role of Shame in Defining Stigmatization." Child Abuse \& Neglect 20(8):767-782.

Fikree, F. F. and O. Pasha. 2004. "Role of Gender in Health Disparity: The South Asian Context." Bmj 328(7443):823-826.

Flood, M. and B. Pease. 2009. "Factors Influencing Attitudes Towards Violence Against Women.” Trauma, Violence, \& Abuse 10(2):125-142.

Go, V. F., C. J. Sethulakshmi, M. E. Bentley, S. Sivaram, A. K. Srikrishnan, S. Solomon, and D. D. Celentano. 2003. "When HIV-Prevention Messages and Gender Norms Clash: The Impact of Domestic Violence on Women's HIV Risk in Slums of Chennai, India." AIDS and Behavior 7(3):263-272.

Goel, R. 2005. "Sita's Trousseau Restorative Justice, Domestic Violence, and South Asian Culture." Violence Against Women 11(5):639-665.

Hameed, S., S. Hlatshwayo, E. Tanner, M. Türker, and J. W. Yang. 2010. Human Trafficking in India: Dynamics, Current Efforts, and Intervention Opportunities for the Asia Foundation. Retrieved (https://asiafoundation.org/resourc es/pdfs/StanfordHumanTraffickingIndiaFinalReport.pdf).

HAQ: Centre for Child Rights. 2010. Child Marriage in India: Achievements, Gaps and Challenges. Retrieved (http:// www.ohchr.org/Documents/Issues/Women/WRGS/Forced
Marriage/NGO/HAQCentreForChildRights1.pdf).

Hennink, M. and P. Simkhada. 2004. "Sex Trafficking in Nepal: Context and Process." Asian and Pacific Migration Journal 13(3):305-338.

Huda, S. 2006. "Sex Trafficking in South Asia." International Journal of Gynecology \& Obstetrics 94(3):374-381.

Indian Penal Code. Prohibition of Child Marriages Act. 2006. Retrieved (http://unicef.in/Uploads/Publications/Resources/ pub_doc102.pdf).

Indian Penal Code-Immoral Traffic Prevention Act. 1956. Retrieved (http://www.hyderabadpolice.gov.in/acts/immora ltraffic.pdf).

International Center for Research on Women. 2011. Evolving Men: Men and Masculinities. Retrieved (http://www.icrw. org/publications/evolving-men).

Kara, S. 2009. Sex Trafficking: Inside the Business of Modern Slavery. USA: Columbia University Press.

Khan, I. N.d. Child Trafficking in India-A Concern. White Paper.

Krishnan, S. 2005. "Do Structural Inequalities Contribute to Marital Violence? Ethnographic Evidence From Rural South India." Violence Against Women 11(6):759-775.

Lanier, M. and S. Henry. 2004. Essential Criminology. Boulder, CO: Westview Press.

Lewis, M. 1992. Shame: The Exposed Self. New York: The Free Press.

Lutya, T. M. and M. Lanier. 2012. An Integrated Theoretical Framework to Describe Human Trafficking of Young Women and Girls for Involuntary Prostitution. INTECH Open Access Publisher.

Men and Gender Equality Policy Project. 2011. Evolving Men: Initial Results From the International Men and Gender Equality Survey-IMAGES. Retrieved (http://www.icrw. $\mathrm{org} / \mathrm{sites} /$ default/files/publications/Evolving-Men-Initial-Re sults-from-the-International-Men-and-Gender-Equality-Sur vey-IMAGES-1.pdf).

Nair, P. M. 2004. A Report on Trafficking of Women and Children in India: 2002-2003. Vol. 1. New Delhi: UNIFEM, ISS, NHRC.

Nair, P. M. and S. Sen. 2004. A Report on Trafficking of Women and Children in India: 2002-2003. Vol. I. New Delhi: UNIFEM, ISS, NHRC.

Okonofua, F. E., S. M. Ogbomwan, A. N. Alutu, O. Kufre, and A. Eghosa. 2004. "Knowledge, Attitudes and Experiences of Sex Trafficking by Young Women in Benin City, South-South Nigeria." Social Science \& Medicine 59(6):1315-1327.

Ross, C. A. 1989. Multiple Personality Disorder: Diagnosis, Clinical Features, and Treatment. New York: Wiley.

Silverman, J. G., M. R. Decker, J. Gupta, A. Maheshwari, V. Patel, B. M. Willis, and A. Raj. 2007. "Experiences of Sex 
Trafficking Victims in Mumbai, India." International Journal of Gynecology \& Obstetrics 97(3):221-226.

Skeldon, R. 2000. "Trafficking: A Perspective From Asia." International Migration 38(3):7-30.

Tangney, J. P., P. Wagner, C. Fletcher, and R. Gramzow. 1992. "Shamed Into Anger? The Relation of Shame and Guilt to Anger and Self-reported Aggression." Journal of Personality and Social Psychology 62(4):669-675.

The British Psychological Society. 2010. Code of Ethics and Conduct. Retrieved (http://www.bps.org.uk/system/files/ Public\%20files/aa\%20Standard\%20Docs/inf94_code_web_ ethics_conduct.pdf).

The U.S. State Department. 2009. Trafficking in Persons 2014 Report. Retrieved (http://www.state.gov/j/tip/rls/tiprpt/coun tries/2014/226740.htm).

UNDP. 2007. United Nations Development Report. Retrieved (http://hdr.undp.org/en/content/adult-literacy-rate-both-sexe s-ages-15-and-older).

UNICEF (United Nations International Children's Emergency Fund). 2015. The State of the World's Children 2015: Executive Summary. Retrieved (http://www.unicef.org/pub lications/files/SOWC_2015_Summary_and_Tables.pdf).

- 1989. United Nations Conventions on Child Rights, Article 34. Retrieved (http://www.unicef.org.uk/Docu ments/Publicationpdfs/UNCRC_PRESS200910web.pdf).

United Nations Office of the High Commissioner for Human Rights. 2015. Preliminary Findings, UN Special Rapporteur on Trafficking in Persons, Especially Women and Children, Maria Grazia Giammarinaro Visit to Malaysia. Retrieved (http://www.ohchr.org/EN/News Events/Pages/DisplayNews.aspx?NewsID=15631\&LangID $=\mathrm{E})$.
United Nations Office on Drugs and Crime. 2000. UN Palermo Protocol Article 3. Retrieved (https://www.unodc.org/ documents/treaties/UNTOC/Publications/TOC\%20Convent ion/TOCebook-e.pdf).

—. 2009. Global Reports on Trafficking. Retrieved (https:// www.unodc.org/documents/human-trafficking/Global_Rep ort_on_TIP.pdf).

- 2012. UNODC Report. Retrieved (https://www.unodc. org/documents/data-andanalysis/glotip/Trafficking_in_Pers ons_2012_web.pdf).

United Nations. 2015. United Nations Millennium Development Goals. Retrieved December 2015 (http://www.un.org/ millenniumgoals/).

Van der Hoven, A. and A. Maree. 2005. "Victimisation Risk Factors, Repeat Victimisation and Victim Profiling." In Victimology in South Africa, edited by L. Davis and R. Snyman. Pretoria: J.L. van Schaik.

Women and Child Development Ministry of India Annual Report. 2014. Retrieved (http://wcd.nic.in/sites/default/ files/AR2013-14.pdf).

\section{Bio}

Madhumita Pandey, BA (Hons), MSc, FHEA-Fellow of the Higher Education Academy, doctoral candidate, working part time as an associate lecturer in the Department of Criminology, Anglia Ruskin University, Cambridge, United Kingdom, previously worked as a consultant psychologist for BBC's documentary India's Daughter; research fields: sexual violence in India, sex trafficking, rape myth attitudes, masculinity ideology and children of prisoners. 